\title{
SMALL BORDER TRAFFIC BETWEEN POLAND AND THE KALININGRAD OBLAST OF THE RUSSIAN FEDERATION AS ONE OF THE ELEMENTS CREATING CROSS-BORDER COOPERATION
}

\section{IWONA BATYK}

\begin{tabular}{|c|c|}
\hline & $\begin{array}{l}\text { University of Warmia and Mazury in Olsztyn, POLAND } \\
\text { e-mail: Iwona.batyk@uwm.edu.pl }\end{array}$ \\
\hline $\begin{array}{l}\text { RECEIVED } \\
\text { ACCEPTED }\end{array}$ & $\begin{array}{l}25 \text { February } 2016 \\
1 \text { June } 2016\end{array}$ \\
\hline $\begin{array}{l}\text { JEL } \\
\text { CLASSIFICATION }\end{array}$ & F50, 012 \\
\hline KEYWORDS & Kaliningrad Oblast of the Russian Federation, small border traffic, cross-border cooperation, border regions \\
\hline ABSTRACT & $\begin{array}{l}\text { The article presents the reasons that affect the small border traffic between Poland and the Kaliningrad Oblast } \\
\text { of Russian Federation, opportunities and barriers that affect the development of the attractiveness of the } \\
\text { Polish-Russian border regions. Theoretical considerations have been supported by the results of empirical } \\
\text { research. The aim of the study was to identify reasons that reduce the attractiveness of the Polish-Russian } \\
\text { border regions. Identified deficiencies in Polish service offer and difficulties of cross-border cooperation. Also, } \\
\text { the article contains statistical data on the development of the small border traffic and expenses incurred by the } \\
\text { Russians during their stay in Poland. }\end{array}$ \\
\hline
\end{tabular}

\section{Introduction}

Currently, in the conditions of the functioning of the Polish economy, the is becoming increasingly important cross-border cooperation and knowledge about the relationship of political, social and economic structures. The cooperation of border regions is realized in the economic and social areas. Directions and objectives of the cooperation determines regional policy, which is modified, depending on the needs, terms the objective integration. 
Based on The European Outline Convention on Transfrontier Co-operation between Territorial Communities or Authorities, also called the Madrid Convention, "transfrontier cooperation shall mean any concerted action designed to reinforce and foster neighbourly relations between territorial communities or authorities within the jurisdiction of two or more Contracting Parties and the conclusion of any agreement and arrangement necessary for this purpose" (The European Outline Convention..., 1993).

The founder of the cross-border cooperation concept defined cross-border regions as united by common history, environment, ethnic group, and economic possibilities, but divided by sovereignty of governments ruling on both sides of the border (Yarovoy, 2007). At the moment, there are different opinions on a question to, what degree a border position affects the development of a region. Some scholars define this factor as one of the key elements that can both stimulate and hamper the development of border territories (Klemeshev, 2007; Vardomsky, 2009; Korneevets, 2010). However, other researchers maintain that cross-border cooperation has a significant effect on the development of a territory. Cross-border cooperation as a type of interregional interaction is becoming a significant factor in socioeconomic development of border regions. Cross-border cooperation is a special kind of interregional interaction determined by territorial vicinity (neighbourhood) of regions (administrative units) of different states; it is a combination of interaction within the nature - population - economy triad, as well as the corresponding structures relating to the adjacent border regions of two states (Mezhevich, Zhuk, 2013).

The article presents the reasons that affect the small border traffic between Poland and the Kaliningrad Oblast of Russian Federation, opportunities and barriers that affect the development of the attractiveness of the Polish-Russian border regions. The article is the result of the analysis of literature, statistical studies and information from the Border Guards of Warmia and Mazury. The information contained in the literature relate only to statistical data. There are no publications on residents' opinions on the impact of local border traffic at regional development. The result of rapidly changing political and economic situation, are the changes in the perception of the benefits of cross-border cooperation. Therefore, theoretical considerations have been supported by the results of empirical research. The aim of the study was to identify reasons that reduce the attractiveness of the Polish-Russian border regions. Identified deficiencies in Polish service offer and difficulties which the Russians are encountered. Also, the article contains statistical data on the development of the small border traffic and expenses incurred by the Russians during their stay in Poland.

\section{Cross-border cooperation between the Pomerania and Warmia and Mazury regions and the Kaliningrad Oblast - opportunities and barriers}

New opportunities for cooperation between the Pomerania and Warmia and Mazury Voivodships and the Kaliningrad Oblast arose after the signing of an agreement on small border traffic on July 27, 2010. This agreement establishes a simplified border crossing procedure for residents of border regions of the two countries. In Russia, it applies to all residents of the Kaliningrad Oblast, in Poland - two Voivodships: Pomerania and Warmia and Mazury. In the Pomeranian Voivodship includes residents of 4 counties: Puck, Nowy Dwór, Malbork and cities: Gdansk, Gdynia, Sopot. In Warmia and Mazury Voivodship - residents 11 counties: Elblag, Braniewo, Lidzbark Warmiński, Bartoszyce, Olsztyn, Kętrzyn, Mraggowo, Węgorzewo, Giżycko, Gołdap and Olecko and cities: Olsztyn and Elbląg (Umowa..., 2012).

Borders can both promote and inhibit the interaction of neighboring countries (Katrovsky, Korneevets, 2015). The possibility of cooperating partners decide about the effects of cross-border cooperation as well as the barriers 
and limitations. The barriers to cross-border cooperation between Poland and Russia are differences in the level of economic diversity of structures of administrative division, the limited entitlements of regional authorities to conduct international cooperation. Centralized management in the Russian Federation makes the Kaliningrad authorities have a small power to cross-border activities. Determinants of cultural, social and moral influence on cooperation with a Russian partner are: the mentality, customs, attitudes towards foreign partners, the style of business contacts, the problem of timeliness, ways of getting information, psychological portrait of the modern Russian entrepreneurs and negative stereotypes. The effect of barriers to cross-border cooperation is the increase of asymmetry of socioeconomic development.

Surveys were conducted in 2012 among 200 respondents from the Kaliningrad Oblast, who were chosen using random selection. The study used a method of face-to-face survey. The research tool was a questionnaire. Presented in this paper results are a part of a wider research. The study involved $50 \%$ of women and $50 \%$ men. Respondents declared higher education (30\%), secondary education (21\%), bachelor (21\%), vocational education $(19 \%)$ and primary education (9\%). The largest group of respondents participating in the study were people aged $36-45$ years $(25.5 \%)$ and $18-25$ years $-25 \%$. Persons aged $26-35$ years accounted for $17.5 \%$ of the respondents. Next groups of respondents in terms of numbers were: persons aged $46-55$ years (22\%) and over 55 years (10\%). Differentiation also related to social status. One in five respondents had their own businesses $(20 \%), 30 \%$ of respondents were employed, government employees $-14.5 \%$, unemployed $-9 \%$ of students $-20 \%$ and pensioners $-6.5 \%$.

The survey indicates, that reduction the tourist attractiveness of the Polish-Russian border regions make: less developed public transport connections (59.5\%) and the disapproval of Poles (local inhabitants) (57.4\%). High prices of Polish products and the low level of service does not affect the reduction the attractiveness of the border regions. The respondents expressed a positive opinion on the quality of Polish products, especially food products and a high level of tourism and medical services. Also, the survey showed the areas were deficiencies in the offer of services for Russian customers: a very limited medical services offer ( $62 \%$ of responses) and holidays offer for children and teenagers ( $40 \%$ of responses). The Russians paid attention to the lack of offers of active tourism (36.5\%) and a low level of the Russian language knowledge among the people who provide services to Russian tourists (34\%). Important deficiencies related to accessibility of services outside the hotel provided. Also very important for the Russians was the lack of service offering of aesthetic medicine, which they are very interested (Batyk, 2013). Polish medical market is seen as very competitive with to the Russian market, and the evaluation is built primarily on the basis of belief functioning in Poland to European standards (affiliation to structures EU forces to provide services at a high level). The main aspects competitiveness is: higher quality of medical services, better equipped clinics and medical centers, more qualified medical staff and better standards of accommodation and meals (Ekspertyza..., 2015).

The main barriers to cooperation between border regions are:

- legal and administrative barriers: incoherent law, complicated border procedures, customs regulations and visa, which depend on the government decisions and policies, the unstable economic situation in the Kaliningrad Oblast,

- political barriers: insufficient support from state institutions,

- social barriers: the low level of people's lives, the differences in mentality, negative stereotypes, lack of knowledge of foreign languages. 
The development of the border regions depends mainly on the government authorities, local governments, the activity of entrepreneurs and non-governmental organizations and associations. Unfortunately, private entrepreneurs are reluctant to engage in public activities. Typical problems of public private cooperation process include: lack of mutual trust and understanding, low level of private involvement, myopic perspective of tourism enterprises in evaluating potential costs and benefits of tourism projects and, finally, private and political misunderstandings (Pawlicz, 2010).

\section{Statistical data on small horder traffic between Poland and the Kaliningrad Oblast}

Small border traffic simplifies procedures for crossing the Polish-Russian border. Consequently, border traffic foreigners and Poles increased as well as expenses incurred in Poland by Russians.

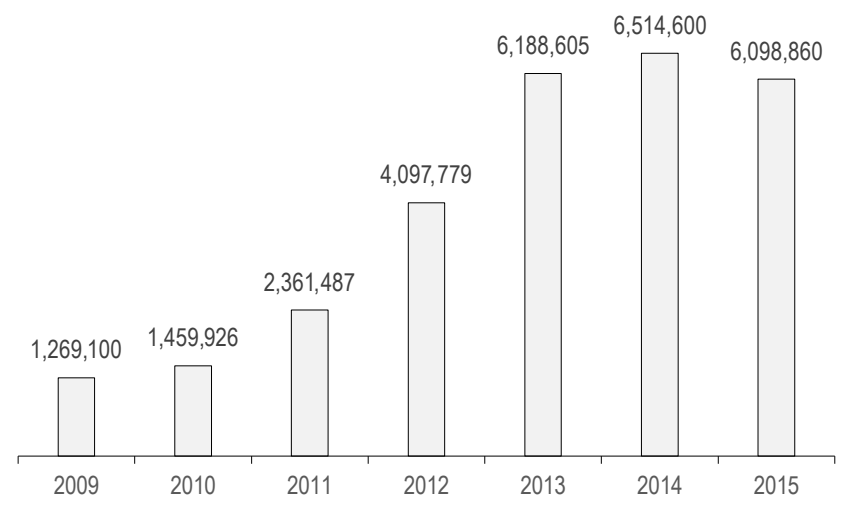

Figure 1. Number of people crossing the Polish-Russian border in 2009-2015

Source: own study based on information the Border Guard of Warmia and Mazury, 2015.

Based on the information the Border Guard Headquarters, in 2013 on the Polish-Russian border in the small border traffic was 1.2 million Russians. Most foreigners crossed the border a few times a month $-66.1 \%$, $25.9 \%$ a few times a week, $6.4 \%$ a few times a year or less, and every day $-1.6 \%$ of Russians (Border traffic and movement..., 2014). Most of them arrived for shopping - 66.8\% and tourism - 15.6\%, for travel arrived 90.507 Russians, which represented $15.6 \%$ of all people crossing the Polish-Russian border in 2013 (Informacja..., 2014). Very popular among Russian tourists was the SPA offer, provided by tourist centers in the border regions.

In 2013, average expenses incurred in Poland by a foreigner crossing the border in the small border traffic was around 376 zł (Polish zloty), and were 5.3\% higher in comparison to the average expenses of other foreigners crossing the Polish-Russian border. Foreigners crossing the border in the small border traffic, about half of expenditure incurred in Poland dedicated for nonfood products (50.5\%), $42.2 \%$ for food products and $7.3 \%$ for other, mainly catering and accommodation (Border traffic and movement..., 2014).

Based on the information the Border Guard Headquarters, the small border traffic in 2014, 1.7 million foreigners benefited (by 44.6\% more than in 2013). After July 2012 and in 2013 small border traffic was characterized by the increasing trend of high dynamics of growth. In 2014, there has been some stabilization. Most foreigners crossed 
the border a few times a month $-58.2 \%, 21.8 \%$ a few times a week, $14.3 \%$ a few times in the quarter, $4.7 \%$ a few times a year or less, and every day $-0.9 \%$ Russians (Border traffic and expenses..., 2015).

In 2014, average expenses incurred in Poland by a foreigner crossing the border in the small border traffic was around $489 \mathrm{zł}$ (29.9\% more than in 2013). Foreigners crossing the border in the small border traffic, about half of expenditure (54.9\%) incurred in Poland dedicated for nonfood goods and $29.4 \%$ for food products and $15.7 \%$ for other (Border traffic and expenses..., 2015). The increase in expenses incurred by the Russians in Poland can positively influence the socio-economic development of border regions, especially in the development of services connected with the visit: accommodation and catering services.

Based on the statistics of the Border Guards, in 2015 Polish-Russian border in the small border traffic was crossed by more than 6 million people, about 500,000 less than last year. Despite the ruble exchange rate in 2015 was low, many Russians did not use the services in Poland. In spite of this, they were coming to buy food (milk, curd, cheese, meat and sausages), which is much more expensive in Russia. Also, the Russians buy the goods for children, clothing, footwear and electronic equipment. From the accounts, which the Russians presented at the border to reclaim tax (tax free), that they released in Poland, less than 180 million zł, in 2014 was nearly 200 million zł. The result of the economic situation in Russia is shopping tourism. Paradoxically, after the start of Russia's embargo on Polish food products, the interest of Russians shopping in Poland has increased.

\section{Conclusions}

Development of cooperation between Polish border regions and the Kaliningrad Oblast depends on many factors, both external and internal. There are mainly restrictions on border crossings, administrative procedures, differences in economic level, as well as differences in lifestyle and cultural differences. The development of trade and services, will depend on the evolution of these factors. Cross-border cooperation should contribute to the development and improvement of living conditions of the residents of the Kaliningrad Oblast and Polish border regions. Despite the existing barriers, cooperation between the Pomerania and Warmia and Mazury regions and the Kaliningrad Oblast is beneficial for regions and their residents. It facilitates the economic and social development of each region, raises standards of living, and ensures a better understanding of foreign partners, which, in its turn, destroys barriers and stereotypes. A small border traffic between Pomerania and Warmia and Mazury regions and Kaliningrad Oblast, contributes to the improvement of cross-border cooperation and developing new forms of business.

\section{References}

Batyk, I.M. (2013). Need to modify travel services offers in response to the demand of the Russian market. Journal of Health Sciences, 3 (8), 145-152.

Cierpiał-Wolan, M., Giełbaga, E. \& Wojnar, E. (2014). Border traffic and movement of goods and services at the European Union's external border on the territory of Poland in 2013. Warszawa-Rzeszów: Central Statistical Office and Statistical Office in Rzeszów.

Cierpiał-Wolan, M. \& Giełbaga, E. (2015). Border traffic and movement of goods and services at the European Union's external border on the territory of Poland in 2014. Warszawa-Rzeszów: Central Statistical Office and Statistical Office in Rzeszów.

Jaroszuk, A. \& Żakowska, B. (2014). Informacja o ruchu turystycznym w województwie warmińsko-mazurskim w 2013 (pp. 32). Olsztyn: Urząd Marszałkowski Województwa Warmińsko-Mazurskiego w Olsztynie.

Katrovsky, A.P. \& Korneevets, V.S. (2007). Current State and Problems of the Border Regions of Russia with Belarus. International Journal of Economics and Financial, 5, 49-54. 
Klemeshev, A.P. (2007). Exclave in the context of globalization: selected publications. Kaliningrad, Russia: Immanuel Kant State University of Russia.

Korneevets, V.S. (2010). Classification of border regions of Russia. Regional Research, 4, 48-53.

Kujawsko-Pomorska Organizacja Pracodawców Lewiatan. (2015). Ekspertyza rynku rosyjskiego w ramach projektu "Branża medyczna siłą regionu kujawsko-pomorskiego". Toruń.

Mezhevich, N. \& Zhuk, N. (2013). Cross-border Specialization of Interregional Interaction: Applying New Assessment Methods. Baltic Region, 1 (15), 27-36.

Pawlicz, A. (2010). Cooperation between tourism industry and public authorities in dissemination of tourism information. The case of West Pomerania Province in Poland. Scientific Journal No. 633 Service Management, 6, 141-151.

The European Outline Convention on Transfrontier Co-operation between Territorial Communities or Authorities. Dz.U. nr 61 z 1993 , poz. 287, 1280.

Umowa między Rządem Rzeczypospolitej Polskiej a Rządem Federacji Rosyjskiej o zasadach małego ruchu granicznego. Dz.U. z dnia 16 lipca 2012 r. poz. 814.

Vardomsky, L.B. (2009). Russia's Economic Space in the Context of Global Financial and Economic Crisis. Journal of The New Economic Association, 3-4, 145-165.

Yarovoy, G.O. (2007). Регионализм и регионализация в транснациональном контексте. In: A.O. Brezman (ed.), Regionalism and cross-border Cooperation in Europe (pp. 145-233). Sankt Petersburg, Russia: Norma.

Cite this anticle aS: Batyk, I. (2016). Small border traffic between Poland and the Kaliningrad Oblast of the Russian Federation as one of the elements creating cross-border cooperation. European Journal of Service Management, 19 (3), 5-10. DOI: 10.18276/ ejsm.2016.19-01. 